Valadez-Manzano et al.

Settlement of spiny lobster postlarvae

Ecosist. Recur. Agropec.

4(11):403-409,2017

\title{
Settlement of the spiny lobster Panulirus inflatus (Bouvier, 1895) postlarvae in the southeastern Gulf of California, Mexico
}

\section{Asentamiento de la postlarva de langosta espinosa Panulirus inflatus (Bouvier, 1895) en el sureste del Golfo de California, México}

\author{
Luis Miguel Valadez-Manzano*, Raúl Pérez-González, David Becerra-Arroyo, Martín Ignacio Borrego \\ ${ }^{1}$ Laboratorio Programa Langosta, Facultad de Ciencias del Mar, Universidad Autónoma de Sinaloa, Paseo Claussen s/n, Col. \\ Centro, CP. 82000, Mazatlán, Sinaloa, México. \\ ${ }^{*}$ Corresponding author: Imvaladez@uas.edu.mx
}

Scientific note: $\quad$ received: october 14, 2014, accepted: may 19, 2016

\begin{abstract}
The settlement of Panulirus inflatus postlarvae in the southeastern Gulf of California was monitored approximately every week at one location (Puerto Viejo Bay) in Mazatlán Bay, from november 2009 to October 2010. Each sampling date was assigned to the lunar phase. Modified sandwich collectors were used to capture postlarval lobsters. Three collectors were used to examine pueruli settlement. A total of $238 \mathrm{P}$. inflatus pueruli were collected, which included 40 pueruli (17\%) and 198 post-pueruli (83 \%). Settlement was highest using collector number one (140 pueruli), and november 2009 was the month with the greatest total number of animals (121). Significant differences were found with respect to the lunar phase, but the higher settlement in this study occurred during the new moon phase.
\end{abstract}

Key words: Gulf of California, Panulirus inflatus, pueruli settlement, modified sandwich collector

RESUMEN. El asentamiento de la postlarva de Panulirus inflatus en el sureste del Golfo de California fue revisado cada semana en una estación de muestreo en la zona denominada Ensenada de Puerto Viejo de la bahía de Mazatlán, Sinaloa, de noviembre 2009 a octubre 2010. Cada fecha de muestreo fue asignada de acuerdo a la fase lunar. En este estudio se utilizaron colectores tipo Sandwich modificado para capturar las postlarvas de langosta. Tres colectores fueron usados para examinar el asentamiento de puérulos de langosta. Se colectó un total de 238 organismos de P. inflatus, 40 puérulos $(17 \%)$ y 198 postpuérulos (83 \%). El mayor asentamiento fue en el colector número uno (140 puérulos) y el mes de noviembre fue cuando se obtuvo la mayor cantidad de organismos (121). Se encontraron diferencias significativas entre las postlarvas y fase lunar, pero los mayores asentamientos ocurrieron en la fase de Luna nueva.

Palabras clave: Golfo de California, Panulirus inflatus, asentamiento de puérulos, Colector Sandwich modificado.

\section{INTRODUCTION}

The lobster fishery in Mexico is important in crustacean exploitation. Lobsters are mainly important from an economic standpoint as they are highrevenue marine products. Seven species of spiny lobsters are found in Mexico, although only four are of commercial importance. Panulirus interruptus (Randall 1840), Panulirus inflatus (Bouvier 1895) and Panulirus gracilis (Streets 1871) are caught mainly along the Mexican Pacific coast, whereas
Panulirus argus (Latreille 1804) is caught in the Caribbean Sea (Pérez-González et al. 1992). The benthic existence of spiny lobsters is preceded by an extraordinarily long (up to 11 months) oceanic larval phase. The oceanic phase is followed by a brief (few weeks) stint in a fast-swimming, non-feeding postlarval phase, which links the offshore life cycle to its inshore, benthic component. The postlarvae of some species settle in crevices, others in architecturally complex vegetation (Butler et al. 2007).

The puerulus is the postlarval stage of spiny 
Valadez-Manzano et al.

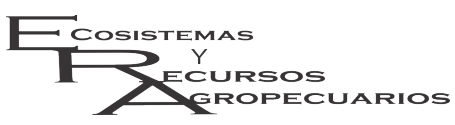

Settlement of spiny lobster postlarvae

Ecosist. Recur. Agropec. 4(11):403-409,2017

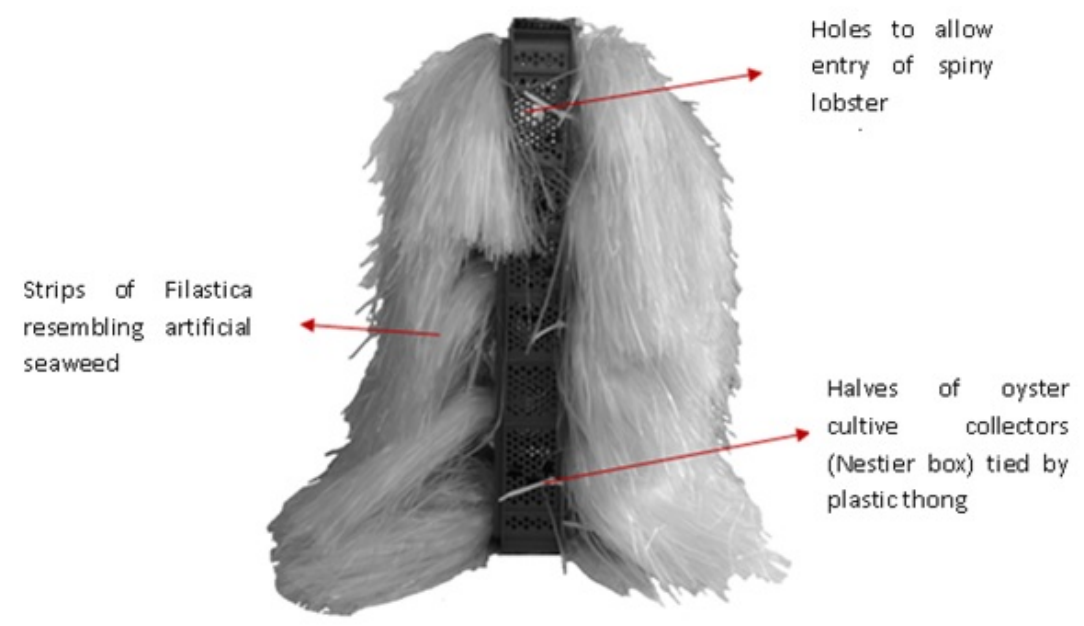

Figure 1. Design of the modified seaweed-type collector used to sample pueruli on the coast of Mexico in Mazatlán Bay, Gulf of California.

lobsters, which resembles the adult lobster, but the body is completely transparent. Settlement refers to the moment when the puerulus ceases any further forward swimming and becomes benthic or colonizes a collector. Attracting devices commonly referred to as collectors have usually been used to capture pueruli. Collectors are typically grouped into two categories: those that imitate seagrasses or algae, commonly referred to as seaweed-type collectors, and those that simulate holes and crevices, known as crevice-type collectors (Phillips and Booth 1994). Both types of collectors have given a good relative measure of the number of pueruli in an area (Witham et al. 1968, Phillips 1972, Montgomery and Craig 1997) and also have been used to predict the level of catch of spiny lobsters in future years. The aim of this study was to investigate lobster postlarval settlement in the coastal waters of Mazatlan Bay, Sinaloa, Mexico, using a modified version of the seaweed-type collector previously described.

\section{MATERIALS AND METHODS}

The Bay of Mazatlán is located in the southeastern part of the Gulf of California between $23^{\circ}$ $12^{\prime} 32^{\prime \prime} \mathrm{N}$ and $106^{\circ} 25^{\prime} 33^{\prime \prime} \mathrm{W}$. From november 2009 to October 2010, we established one sampling sta- tion (Puerto Viejo Bay) with three collectors parallel to the coastline. Each collector was anchored at a depth of $\sim 1 \mathrm{~m}$ in water $\sim 2 \mathrm{~m}$ deep over a rocky and sandy bottom substrate with surrounding macroalgae (Padina durvillaei and Ulva lactuca) in the area of Puerto Viejo Bay. The collectors were set with a minimum spacing of $20 \mathrm{~m}$ between individual collectors. Sampling occurred weekly.

The design of the collector used was the seaweed-type collector modified as described by Montgomery and Craig (1997). The collector has as its frame two halves of an oyster culture collector (Nestier box) tied by a plastic thong. The collectors were set attached to concrete weights (30 or $33 \mathrm{~cm}$ in radius, concrete-filled car tire, $35 \mathrm{~kg}$ in weight) linked along the sea floor by $3 \mathrm{~m}$ of synthetic ropea total of 12 tassels of a synthetic fiber (filastica) commonly used in the manufacture of defenses for shrimp trawling nets. The tassels were attached to the outer face of each half (Figure 1). During collection, each half of the seaweed-type collector was taken from the frame and shaken 30 times into a $170 \mathrm{~L}$ container, and the catch obtained was passed through a mesh sieve. All pueruli were counted and staged. For this study we defined the puerulus stage as those organisms that were transparent with a smooth carapace, whereas the postpuerulus stage 
Valadez-Manzano et al.

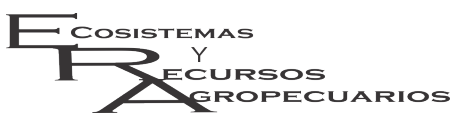

Settlement of spiny lobster postlarvae

Ecosist. Recur. Agropec.

4(11):403-409,2017

was defined as those organisms that were brown in color with spines on the carapace (Lewis et al. 1952). The postlarvae were recorded and returned to the sea far from the collectors to avoid recolonization. During each sampling, the subsurface sea water temperature was recorded.

Weekly catch data were pooled to obtain the data by month. The catch per unit effort (CPUE) was determined by dividing the catch of $P$. inflatus postlarvae by the number of collectors examined per month. A Chi-square test was performed to evaluate the differences among the monthly catches. We applied this same test to compare the postlarval abundance and lunar periodicity. The effect of the location of each collector on the settlement of lobster postlarvae was analyzed by means of a Chisquare test (Zar 1999). The Statistica program was used in the different tests with a significance level of $\mathrm{a}=0.05$.

\section{RESULTS AND DISCUSSION}

The seasonal variation in subsurface water temperature ranged from $24.8^{\circ} \mathrm{C}$ to $32.9^{\circ} \mathrm{C}$. The temperature increased from may to august and began decreasing from september to november. Annual lows occurred in april-may and highs in august. A total of 238 postlarvae were collected, which included 40 pueruli (17\%) and 198 postpueruli (83 $\%)$. Although some settlement occurred throughout the year, except in august when the collection was nil, the main peak was during november 2009 (121 pueruli) with a smaller peak (32 pueruli) in february 2010 (Figure 2). The Chi-square test showed significant differences among the monthly catches throughout the annual cycle $(p<0.05)$.

Settlement occurred primarily during the new moon (98 specimens), followed by the third-quarter (70 postlarvae), first-quarter ( 45 organisms) and full moons (23 specimens) (Figure 3). The postlarval catch differed significantly among the lunar phases (Chi-square test, $p<0.05$ ). Settlement was highest for collector number one. Over the sampling period, 130 pueruli settled on this collector. The next highest settlement was on collector numbers two and three with 50 and 58 postlarvae, respectively (Figure 4). The Chi-square tests indicate that only the catches in collector number one were significantly different $(p<0.05)$.

A total of 238 postlarvae were caught during the study period. The CPUE showed a descending pattern during the 12 months of this study; the catch ranged from 12.1 (november 2009) to 0 (August 2010) pueruli/collector/month (Table 1). However, the maximum in march (17.0 CPUE) corresponds to the examination of only one collector because the remaining collectors were lost and could not be replaced until may. The overall CPUE during the study period was 4.2 pueruli/collector/month. The collector used in this study was a modified version of a design described by Montgomery and Craig (1997). The results from this study suggest that this new collector design was useful in measuring the settlement rate of Panulirus inflatus postlarvae, 238 of which were caught during the study period. PérezGonzález (2016) collected a total of 37 pueruli (nine pueruli and 28 postpueruli) using the GuSi seaweed collector in the same area. Briefly, the GuSi collector (Gutierrez-Carbonell et al. 1992) consists of a $20 \mathrm{~L}$ plastic bucket covered by filastica. Once the collector is assembled, it simulates a seaweed habitat. Probably the fact that few pueruli were caught by Pérez-González can be associated with the design and inefficiency of this collector. According to morphological observations made on some of the postlarvae, the postpuerulus stage corresponded to Panulirus inflatus because the distinctive features of the organisms presented were appropriate to that species.

Settlement of pueruli occurred throughout the year, with peaks in autumn (November) and winter (February). When temperatures were highest (August), settlement was insignificant. CaballeroFuentes and Torres-Zepeda (2008) reviewed the spatial and temporal variation of the catches of Panulirus inflatus puerulus larvae in different areas of Acapulco Bay; the observed peak in november in our study coincides with the temporal pattern described by these authors. 
Valadez-Manzano et al.

Ecosistemas

PeCursos

Zecursos
Settlement of spiny lobster postlarvae

Ecosist. Recur. Agropec.

4(11):403-409,2017

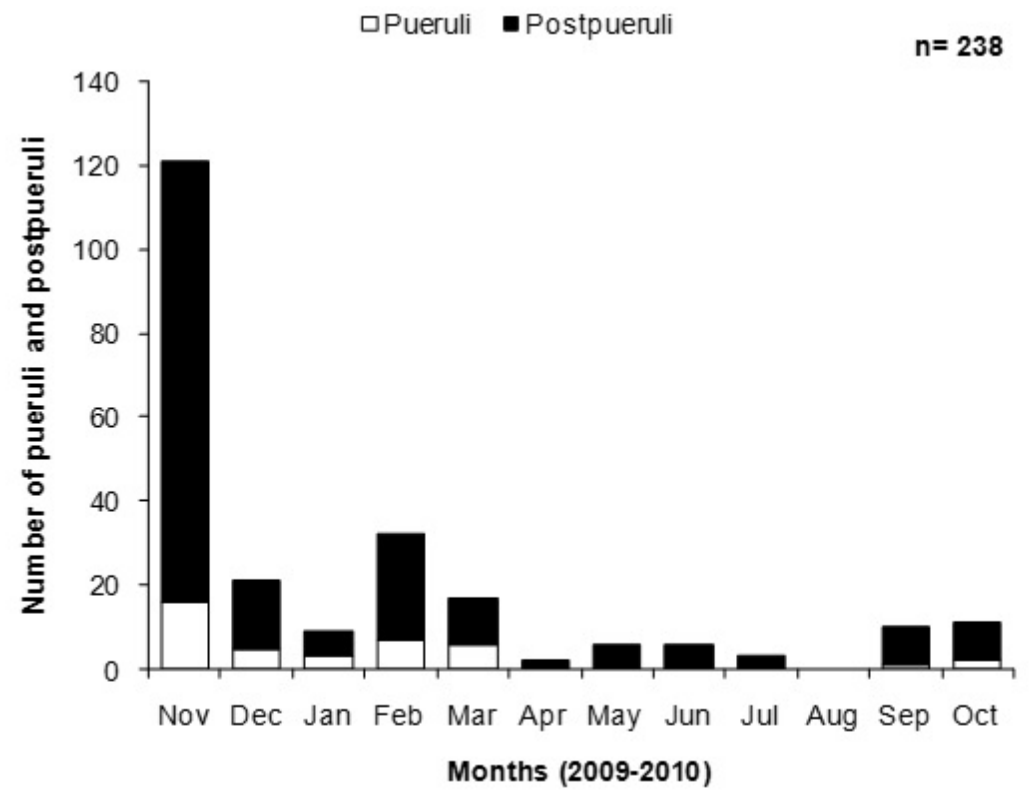

Figure 2. Monthly number of Panulirus inflatus pueruli and postpueruli caught in the modified seaweed-type collector. Different letters above the bars denote significant differences between the monthly catches of postlarvae (Chi-square test, $p<0.05$ ).

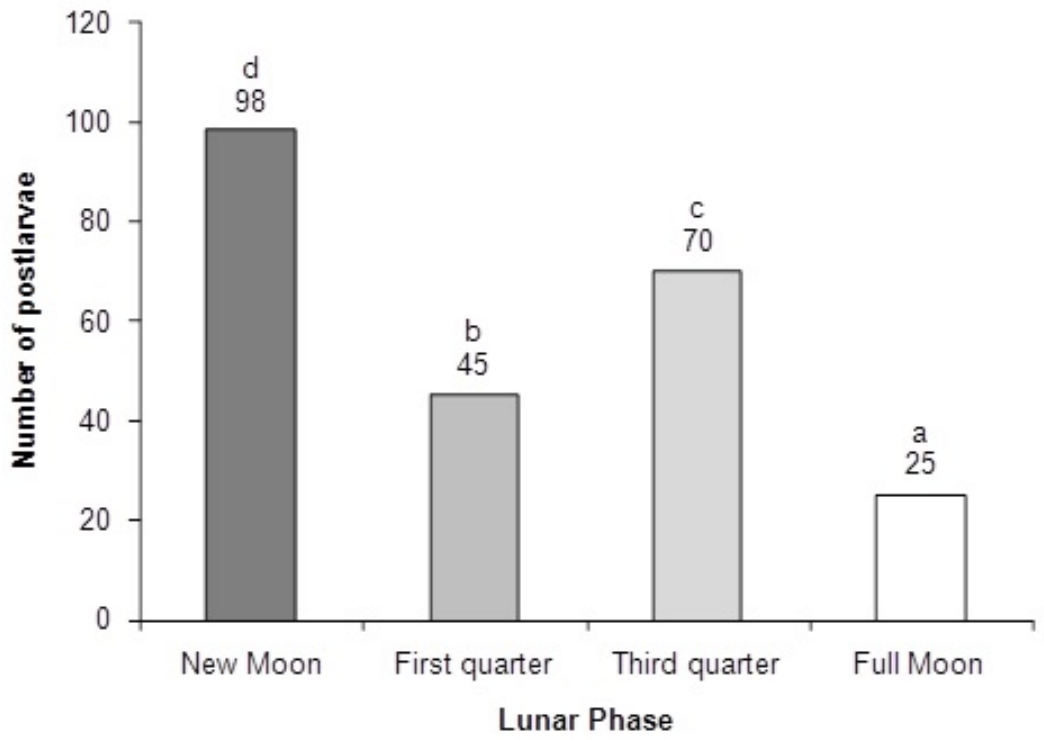

Figure 3. Catches of Panulirus inflatus postlarvae as a function of moon phase. Different letters above the bars denote significant differences between the number of postlarvae and the moon phases (Chi-square test, $\mathrm{p}<0.05$ ).

Although significant differences were found in the catches of postlarvae according to the moon phase, the highest captures were obtained during the new moon, followed by third and first quar- 
Valadez-Manzano et al.

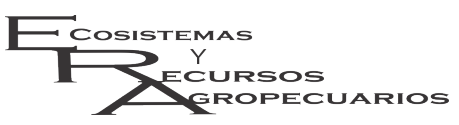

Settlement of spiny lobster postlarvae

Ecosist. Recur. Agropec.

4(11):403-409,2017

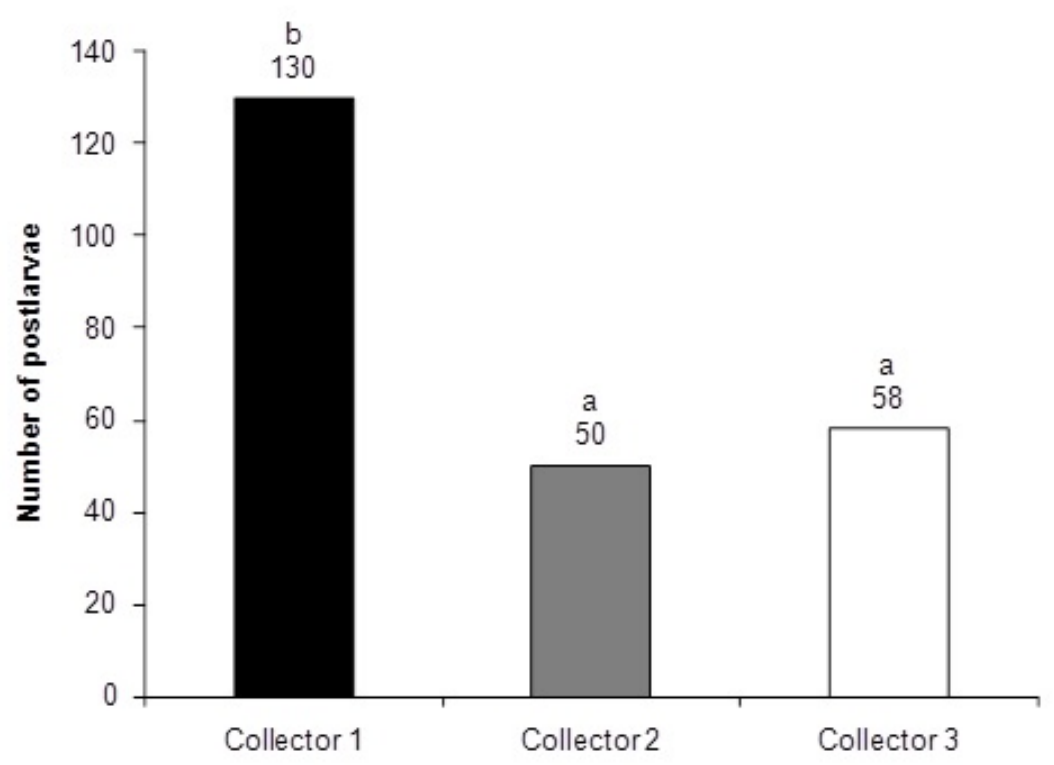

Figure 4. Catches of Panulirus inflatus postlarvae by collector. Different letters above the bars denote significant differences between the captures per collector (Chi-square test, $\mathrm{p}<0.05)$.

Table 1.Total pueruli, total number of collectors examined per month and catch per unit effort per month (CPUE).

\begin{tabular}{lccc}
\hline Month & $\begin{array}{c}\text { Total } \\
\text { caught }\end{array}$ & Number of examinations per month & CPUE \\
\hline November 2009 & 121 & 10 & 12.1 \\
December & 21 & 6 & 3.5 \\
January 2010 & 9 & 3 & 3.0 \\
February & 32 & 8 & 4.0 \\
March & 17 & 1 & 17.0 \\
April & 2 & 1 & 2.0 \\
May & 6 & 4 & 1.5 \\
June & 6 & 5 & 1.2 \\
July & 3 & 2 & 1.5 \\
August & 0 & 2 & 0.0 \\
September & 10 & 3 & 3.3 \\
October & 11 & 12 & 0.9 \\
Overall & 238 & 57 & 4.2 \\
\hline
\end{tabular}

ters. This was also reported for other species such as $P$. argus (Little and Milano 1980, Marx and Herrnkind 1985, Monterrosa 1991, Briones and Gutierrez 1992, González and Wehrtmann 2011), P. cygnus (Phillips 1972, 1975) and P. marginatus (MacDonald 1986). Caballero-Fuentes and TorresZepeda (2008) reported more $P$. inflatus postlarvae catches during the new moon and first quarter phases than during last quarter or full moon, which is in accordance with the data obtained in the present study. Darkness will reduce the predation risk during settlement of the pueruli (which resemble adults in structure, but are completely transparent), and other factors such as local current patterns may influence whether recruitment is more pronounced during the new moon or first-quarter moon phase.

Of the three collectors sampled, collector number one was most subject to the direct influences of sea water entering the bay and consistently caught larger numbers of postlarvae (Figure 4). 
Valadez-Manzano et al.

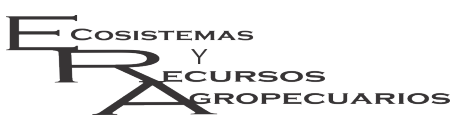

Settlement of spiny lobster postlarvae

Ecosist. Recur. Agropec.

4(11):403-409,2017

Phillips (1975) suggested that postlarvae may make use of the incoming water currents to approach the coastal areas where they would eventually settle. A similar mechanism could be operating in Puerto Viejo Bay, thus explaining the large number of postlarvae in collector 1 and smaller numbers in collectors 2 and 3. However, little information is available on current patterns in the Bay of Mazatlan, and longer-term studies on this subject are required.

The CPUE of 4.2 pueruli per collector agrees with the results (0 to 2.52) for P. interruptus reported by Guzmán del Proo et al. (1996) using the GuSi collector. Our data are also close to those reported by González and Wehrtmann (2011), who found an overall CPUE of 5.63 for $P$. argus using the same type of collector. These results are very similar despite differences in the length of the sampling times (weekly, monthly and fortnightly). The maximum catch obtained in this study (238 pueruli) may appear very low compared with the results of other types of collectors; for instance, 4000 organisms were caught with the Booth collector (Booth 1989), and 529 and 1907 pueruli were caught with the GuSi collector (Briones and Gutierrez 1992, González and Wehrtmann 2011). However, it should be noted that the dimensions of each collector are different and do not necessarily provide the same surface for settlement. Moreover, the variation is probably associated with various sampling techniques in different habitats as well as with regional variability.

\section{ACKNOWLEDGEMENTS}

We gratefully acknowledge the invaluable assistance of student Ruth Estrada Barron in our field and laboratory work. Thanks are also due to the fishery biologist Onesimo Lopez Ramos for logistic and nautical support. Dr. José Cristóbal Román Reyes provided invaluable assistance with the statistical analyses. This study was partially funded by the Universidad Autónoma de Sinaloa through the project "Evaluacion del reclutamiento de postlarvas de las langostas Panulirus spp. en el sur de Sinaloa" (clave: PROFAPI2011/125).

\section{LITERATURE CITED}

Booth J (1989) Ocurrence of the puerulus stage of the rock lobster, Jasus edwardsii at the New Plymouth Power Station, New Zealand. New Zealand Journal of Marine and Freshwater Research 23: 43-50.

Briones P, Gutiérrez D (1992) Postlarval recruitment of the spiny lobster, Panulirus argus (Latreille 1804), in Bahia de la Asención, Proceedings of the Gulf and Caribbean Fisheries Institute 41: 492-507.

Butler MJ, Steneck RS, Herrnkind WF (2007) Juvenile and adult ecology. In: Phillips BF (ed) Lobsters: Biology, management, aquaculture and fisheries, Blackwell Publishing Ltd, Oxford. pp: 263-266.

Caballero-Fuentes R, Torres-Zepeda M (2008) Variabilidad espacial y temporal en la captura de puérulos de langosta espinosa Panulirus inflatus (Bouvier, 1895) en la bahía de Acapulco y zonas cercanas, Guerrero, México. En: Memorias del IV Foro Científico de Pesca Ribereña. Acapulco, Guerrero. pp: 47-48.

González O, Wehrtmann IS (2011) Postlarval settlement of spiny lobster, Panulirus argus (Latreille, 1804) (Decapoda: Palinuridae), at the Caribbean coast of Costa Rica. Latin American Journal of Aquatic Research 39: 575-583.

Gutiérrez-Carbonell, D, Simonin-Díaz J, Briones-Fourzan P (1992) A simple collector for postlarvae of the spiny lobster Panulirus argus. Proceedings of the Gulf and Caribbean Fisheries Institute 41: 516-527.

Guzmán Del Proo J, Carrillo-Laguna J, Belmar-Pérez S, de la Campa J, Villa A (1996) The puerulus settlement of red spiny lobster (Panulirus interruptus) in Bahía Tortugas, Baja California, México. Crustaceana 69: 949-957.

Lewis JB, Moore HB, Babis W (1952) The post-larval stages of the spiny lobster Panulirus argus. Bulletin of Marine Science of the Gulf and Caribbean 2: 324-337. 
Little EJ, Milano GR (1980) Techniques to monitor recruitment of postlarval spiny lobsters, Panulirus argus, to the Florida Keys. Florida Dept. of Natural Resources, Marine Research Laboratory. Florida Marine Research Publications. Florida, USA. 16p.

MacDonald CD (1986) Recruitment of the puerulus of the spiny lobster, Panulirus marginatus, in Hawaii. Canadian Journal of Fisheries and Aquatic Sciences 43: 2118-2125.

Marx JM, Herrnkind WF (1985) Macroalgae (Rhodophyta: Laurencia spp.) as habitat for young juvenile spiny lobster, Panulirus argus. Bulletin of Marine Science 36: 423-431.

Monterrosa OE (1991) Postlarval recruitment of the spiny lobster, Panulirus argus (Latreille) in Southwestern Puerto Rico. Proceedings of the Gulf and Caribbean Fisheries Institute 40: 434-451.

Montgomery SS, Craig JR (1997) A strategy for measuring the relative abundance of pueruli of spiny lobster Jasus verreauxi. In: Hancock DA, Smith DC (ed) Fisheries resources. The state of science and Management. 2nd World Fisheries congress proceedings. Collingwood, Australia. pp: 574-578.

Pérez-González R, Flores-Campaña LM, Nuñez-Pasten A, Ortega-Salas AA (1992) Algunos aspectos de la reproducción en Panulirus inflatus (Bouvier, 1895) y Panulirus gracilis Streets (Decapoda: Palinuridae) en el sureste del Golfo de California, México. Investigaciones Marinas CICIMAR 7: 25-33.

Pérez-González R, Puga D, Valadez LM, Rodríguez-Domínguez G (2016) Occurrence of Panulirus inflatus (Decapoda: Palinuridae) pueruli in the southeastern Gulf of California, Mexico. Revista de Biología Marina y Oceanografía 51: 209-215.

Phillips BF (1972) A semi-quantitative collector of the puerulus larvae of the western rock lobster Panulirus longipes cygnus George (Decapoda: Palinuridae). Crustaceana 22: 147-154.

Phillips BF (1975) The effect of water currents and the intensity of moonlight on catches of the puerulus larval stages of the western rock lobster. Aust. CSIRO, Div. Fish. Oceanogr. Rep. No. 63. 9p.

Phillips BF, Booth JD (1994) Design, use and effectiveness of collectors for catching the puerulos stage of spiny lobster. Reviews in Fisheries Science 2: 255-289.

Witham R, Ingle RM, Joyce EA (1968) Physiological and ecological studies of Panulirus argus from the St. Lucie Estuary. State of Florida Board of Conservation Technical Series 53. 31p.

Zar JH (1999) Biostatistical Analysis, 4th Edition. Prentice-Hall. New Jersey, USA. 663p. 
